\title{
An Empirical Study on Improving Quality of Coal-Mining Refuse for Re-Vegetation Using Amendments
}

\author{
Ruiqiang Liu $^{1} \&$ Rattan Lal $^{1}$ \\ ${ }^{1}$ Carbon Management \& Sequestrationt Center, School of Environment \& Natural Resources, the Ohio State \\ University, Columbus, Ohio, USA \\ Correspondence: Ruiqiang Liu, Carbon Management \& Sequestration Center, School of Environment \& Natural \\ Resources, the Ohio State University, 210 Kottman Hall, 2021 Coffey Road, Columbus, Ohio 43210, USA. Tel: \\ 614-292-9049. E-mail: liu.603@osu.edu
}

Received: October 29, 2013 Accepted: November 20, 2013 Online Published: November 25, 2013

doi:10.5539/jsd.v6n12p44

URL: http://dx.doi.org/10.5539/jsd.v6n12p44

\begin{abstract}
Re-vegetation on closed mining-sites for carbon sequestration and/or bio-energy production is one of the strategies of addressing the world-wide issues of energy crisis and global warming. However, mine soils including coal-mining refuse usually have poor quality and are unfavorable to plant growth. Thus, the major objective of this study was to improve quality of coal-mining refuse under laboratory conditions using zeolite, flue gas desulfurization gypsum (FGD), flyash, and biosolids at $10 \%(\mathrm{w} / \mathrm{w})$ rate. Chemical analysis did not indicate any significantly high concentrations of toxins in the solid or the solution phase, suggesting that soil acidity was the principal chemical constraint hindering re-vegetation. In this context, FGD was the best among the tested materials for increasing soil $\mathrm{pH}$ and improving lettuce (Lactuca sativa) seed germination, while application of biosolids significantly enhanced soil aggregate stability. Specifically, laboratory tests showed that application of FGD increased $\mathrm{pH}$ of the acidic coal refuse samples from initial 3.80-4.66 to 5.70-6.60 and enhanced the growth of germinated lettuce seedlings in mine soil solution from $2.9-4.4 \mathrm{~cm}$ to $5.9-8.6 \mathrm{~cm}$. The biosolids amendment increased the geometric mean diameter of the mine soil aggregates from the antecedent 0.93-0.99 $\mathrm{mm}$ to $1.13-1.25 \mathrm{~mm}$. However, use of zeolite and fly-ash did not significantly improve the soil quality.
\end{abstract}

Keywords: mine soil, coal refuse, reclamation, soil quality, amendments, carbon sequestration, bio-energy production

\section{Introduction}

Minesoils are formed on landscapes altered by mining processes, particularly by the surface mining operations. A mine soil material is a structureless agglomeration of fragmented rock, subsoil, and the soil that is often less weathered than the original soil profiles that it has replaced (Angel et al., 2008). Mine soils also include ore waste and coal refuse. Coal refuse is regarded as the low-grade coal material extracted along with the coal ore. The former is separated from the latter through coal processing and then discarded. The refuse is usually composed of rock fragments derived from interseam shale or siltstone partings and waste rock materials from above or below the coal seam. The refuse shares many properties with the associated coal seam and still contains a certain amount of coal (or energy). Considering a 30 percent refuse generation rate and 1094.3 million tons of coal production in the USA (National Mining Association, 2012) in 2011, an estimated 328.3 million tons of coal refuse may have been generated in that year alone. Besides occupying lands for its disposal, the potential hazards of improperly reclaimed refuse include contamination of surface and groundwater by acidic leachates and runoff, erosion and sedimentation into nearby water bodies, spontaneous combustion, and damage from landslides (Daniels \& Stewart, 2000; Daniels et al., 2010).

Proper reclamation of mine soils not only benefits the local environment but also contributes to the offsetting of $\mathrm{CO}_{2}$ emissions from industrial activities by storing carbon (C) in vegetation (e.g., Lal \& Bruce, 1999; Nabuurs et al., 2000) and soil (Shrestha et al., 2009). In addition, growing biofuel feedstock crops on marginal lands (e.g., closed-mining sites covered with mine soils or coal refuse) has been increasingly accepted as a sustainable alternative to food-crop-based bio-enegy production (Tilman et al., 2006; Gelfand et al., 2013) without risks of competing for fertile agricultural land or damaging the environment. Overall, $\mathrm{C}$ sequestration and bio-energy 
production in mine soils have created a new concept of mine soil reclamation in sustainable development of the world economy and environmental protection.

Effective $\mathrm{C}$ storage and bio-fuel production require high soil quality so that the vegetation can be easily established and maintained for a long period (e.g., 50 years), even with a limited management. However, a mine soil (i.e., coal refuse) usually has poor soil quality including low content of soil organic matter (SOM), infertility, micronutrient imbalances or toxicity, soil compaction, low moisture holding capacity, high electrical conductivity (EC), and extreme pH (Stewart \& Daniels, 1992; Daniels \& Stewart, 2000; Daniels \& Zipper, 2010) These properties result in unfavorable conditions for both soil organic C (SOC) sequestration and biomass production. Therefore, soil amendments and proper management are often needed to improve soil physical, chemical, and biological quality of a drastically disturbed mine site in order to establish the vegetation and create effective sinks of atmospheric $\mathrm{CO}_{2}$. A number of amendments have been tested to improve the mine soil quality for successful reclamation, SOC sequestration and production of biofuel feedstock. For example, manure, compost, biosolids, paper-mill sludge, and sawdust have been successfully applied to increase the SOM levels and improve the physical and chemical properties of a range of mine soils (Daniels \& Haering, 1994; Li \& Daniels, 1997; Coyne et al., 1998; Roberts et al., 1988; Haering et al., 2000; Bendfeldt et al., 2001; Tompson et al., 2001; Larney et al., 2005; Forsberg \& Ledin, 2006; Shipitalo \& Bonta, 2008; Shrestha et al., 2009; Pérez-estebana et al., 2012). Limestone and coal combustion byproducts (e.g., fly-ash, bottom ash, and flues gas desulfurization gypsum or FGD) have been widely used and extensively researched for reducing mine soil acidity (Bhumbla et al., 2000; Dick et al., 2000; Stewart et al., 2001; Daniels et al., 2002; Shukla et al., 2005; Carter et al., 2009). Various commercial N, P, and K fertilizers have also been applied to provide effective and sufficient nutrient concentrations for vegetation establishment on mined soils (Daniels \& Stewart, 2000; Bendfeldt et al., 2001; Larney et al., 2005; Jacinthe \& Lal, 2007; Shrestha et al., 2009).

Therefore, the overall objective of this study was to improve quality of mine soil so as to satisfactorily establish vegetation cover for $\mathrm{C}$ sequestration by using coal refuse as a growing medium in eastern Ohio, where piles of coal refuse are scattered inside the reclaimed forests. No vegetation had established on these piles. Laboratory studies were initiated to evaluate how selected amendment materials could improve the mine soil quality and facilitate healthy-vegetation establishment and to identify the best amendment(s) for these specific mine soils (coal refuse). The specific objectives of this laboratory study were to:

i. examine the quality and chemical composition of the two coal refuse samples (denoted as mine soils hereinafter unless specified);

ii. study the effects of selected amendments on the elemental (especially toxic ones) concentrations in the water solutions of the soils;

iii. test the effects of amendments on mine soil $\mathrm{pH}$;

iv. evaluate the effects of amendments on lettuce (Lactuca sativa) seed germination in mine soil solutions;

v. assess the influences of amendments on physical properties of these mine soils such as aggregate stability and water holding capacity; and

vi. identify the best amendment for these specific soils.

\section{Materials and Methods}

\subsection{Sampling Site}

Samples were taken from two coarse coal refuse piles in reclaimed forests near the city of Lisbon $\left(40^{\circ} 46^{\prime} 26^{\prime \prime} \mathrm{N}\right.$, $80^{\circ} 46^{\prime} 3^{\prime \prime} \mathrm{W}$ ), Columbiana County, Ohio. Large bulk samples (4 kg) were obtained by combining several subsamples taken at random from the surface (upper $10 \mathrm{~cm}$ ) of each pile. These piles were 90 to 100 years old (pers. comm. with Mark L. Smith, Division of Mineral Resources Management, Ohio Department of Natural Resources). Ohio was one of the earliest states in the US to start coal mining, the first coal production occurred in Jefferson County circa 1800 (Crowell, 1995). Coal production began in Columbiana County in 1803 when 100 tons of coal was reportedly mined (Crowell, 1995). From 1803 until 1993, 96 million tons of coal was mined in Columbiana County (Crowell, 1995). The prevailing rocks nearest the surface are of the Pennsylvania formations consisting of shale, limestone, and sandstone, all with intermingled layers of coal and commercially important clays (http://www.columbianacounty.org).

\subsection{Chemical Analysis of Soils and Amendments}

The two samples (denoted as A and B) were air-dried, hand-crushed to pass through a 2-mm sieve, and then stored for subsequent chemical analyses and testing. Color of the dry samples was determined using the Munsell 
color charts (Nandi \& Luffman, 2012). The pH and electrical conductivity (EC) of the soils and amendments were measured in 1:4 (solid weight: DI water weight) soil slurries. This ratio was identical to the soil solution ratio later used for chemical analyses and germination tests so that the $\mathrm{pH}$ could be applied to these soil elutriates (Bowers et al., 1997). Soil pH can be measured at soil:water ratios of 1:1, 1:2, 1:5 and 1:10, and slightly different results are usually obtained (Tan, 2005). Dilute soil solutions (e.g., 1:10 ratio) usually have higher $\mathrm{pH}$ values than their concentrated counterparts (e.g., 1:1 ratio). However, the $\mathrm{pH}$ difference can be less than 0.4 units between the values measured at 1:1 and 1:10 ratio (Thomas, 1996). The preliminary data of this study showed that the soil $\mathrm{pH}$ measured at the $1: 4$ ratio was only 0.1 to 0.2 units higher than that measured at a 1:1 ratio. Therefore, $\mathrm{pH}$ values presented in this paper at a 1:4 ratio are comparable to those obtained at 1:1 or 1:2 reported elsewhere. Total elemental concentrations in the solids (soils and amendments) were analyzed using an ICP spectrophotometer (Teledyne Leeman Labs, New Hampshire) after the samples were digested in concentrated hydrofluoric acid / perchloric acid (Soltanpour et al., 1996). Concentrations of carbon and nitrogen were measured using the dry combustion method by a Vario Max $\mathrm{C} / \mathrm{N}$ analyzer (Elementar Americas, Inc., New Jersey) (Nelson \& Sommers, 1996; Bremner, 1996). Water-stability of soil aggregates was tested and calculated using the method by Kemper and Rosenau (1986). Soil water-holding capacity (WHC), comprising of saturated water content, field capacity, and permanent wilting point, were estimated at $0 \mathrm{MPa}$ (under the ambient atmosphere), $-0.03 \mathrm{MPa}$, and -1.5 MPa, respectively, after the samples were saturated with water for $12 \mathrm{~h}$ (Cassel \& Nielsen, 1986). Soil available water capacity (AWC) was approximated by the difference between the moisture contents at field capacity (-0.03 MPa) and the permanent wilting point $(-1.5 \mathrm{MPa})$.

\subsection{Amendment Test}

Samples A and B were, respectively, treated at room temperature $\left(\sim 25^{\circ} \mathrm{C}\right)$ with five amendments (coarse zeolite with a grain size of $0.4 \sim 1.4 \mathrm{~mm}$, fine zeolite with a grain size $<0.04 \mathrm{~mm}$, FGD, flyash, and biosolids) at a ratio of $10 \%$ by weight. Deionized (DI) water was added to each mixture to attain field moisture capacity. Each amendment was tested in triplicate. Samples of the mixtures (about $100 \mathrm{~g}$ ) were taken periodically over $35 \mathrm{~d}$ for $\mathrm{pH}$ measurement, and for determining how long an amendment would take to improve soil $\mathrm{pH}$ and reach the reaction equilibrium. After $35 \mathrm{~d}$, the remaining samples were air dried and stored for subsequent elemental analyses, germination tests, and measurement of physical properties.

\subsection{Soil Solution Preparation and Analysis}

Soil solution was prepared from each post-incubated soil sample using a 1:4 (w/w) mixture of soil and DI water according to the method outlined in Bowers et al. (1997). Soil mixtures were constantly stirred for a minimum of $1 \mathrm{~h}$ on an automatic shaker, followed by 1 -h settling, and filtration through a $0.45-\mu \mathrm{m}$ Millipore filter. The filtrates were used for following germination tests and for solution elemental analysis.

\subsection{Seed Germination Test}

The phytotoxicity of the post-incubated soils was determined using 5-d seed germination (Bowers et al., 1997). Tests were conducted using Buttercrunch lettuce (Lactuca sativa) seeds purchased from a local nursery (Columbus, Ohio). Test seeds were selected for uniform size and color after screening through a \#20 sieve to remove the small seeds. Seed germination tests were conducted by placing 10 seeds in $10 \mathrm{ml}$ of filtrated soil solution contained in clear, polystyrene Petri dishes $(9 \times 50 \mathrm{~mm})$ with leak-proof covers. Three replicates of 10 seeds each were prepared for each solution sample. Tests were initiated within $24 \mathrm{~h}$ of preparation of the solution. Control treatments (3 replicates) were prepared in a similar fashion using distilled water and potting-soil solution as the test media. Test containers were incubated at $25^{\circ} \mathrm{C}$ under a light-dark cycle of $18 \mathrm{~h}$ and $6 \mathrm{~h}$, respectively, at approximately $38 \mathrm{mE} \mathrm{m}^{-2} \mathrm{~s}^{-1}$ for a period of $5 \mathrm{~d}$ (incubator manufactured by Percival Scientific Inc., Iowa). After $5 \mathrm{~d}$, the total number of germinated seeds was recorded and the percent germination determined for each elutriate. The germination was considered successful if the primary root length was $\geq 3 \mathrm{~mm}$. The final length of each germinated seedling was measured using a caliper (Bel-Art Products, New Jersey).

All data were statistically analyzed by computing the one-way ANOVA using Minitab 16.1.1 (LEAD Technologies, Inc., North Carolina ). Treatment differences were assessed at $p<0.05$.

\section{Results and Discussion}

\subsection{Chemical Composition of Mine Soils and Amendments}

The data of total elemental analyses (Table 1) show that both soils contained significant amounts (15.3 and 13.6 $\mathrm{g} \mathrm{kg}^{-1}$ soils) of sulfur (S), which most likely originated as the coal-mining by-product - pyrites (FeS). When exposed to the air during mining, the minerals are oxidized into sulfuric acid, resulting in mine soil acidification and high soil $\mathrm{S}$ concentration. In comparison, total $\mathrm{S}$ in surface soils $(0-10 \mathrm{~cm})$ of 35 cultivated sites in the Great 
Plains ranges from 0.15 to $1.2 \mathrm{~g} \mathrm{~kg}^{-1}$ (Wang et al., 2006), 10 to 100 times lower than what was measured in these mine soils, indicating that soil $\mathrm{S}$ content differs significantly between mined and agricultural soils. In addition, pyrite oxidation also caused the low pH of both soils (4.66 and 3.80). Further, in comparison with those reported in US agricultural soils, higher amounts of some toxic elements $(\mathrm{Be}, \mathrm{Cu}, \mathrm{Cr}, \mathrm{Pb}, \mathrm{Se}, \mathrm{Sr}$, and $\mathrm{Zn}$ ) were found in both mine soils. For example, Be concentrations in these mine soils were 5.5-8.5 times higher than those in agricultural soils (Table 1). Coal is often enriched in Be (Kabata-Pendias \& Pendias, 1984), and Be concentrations of 15-50 times higher than the background level $\left(1 \mathrm{mg} \mathrm{kg}^{-1}\right)$ in the vicinity of smelters and coal power stations are often reported (Kabata-Pendias \& Pendias, 1984). Therefore, it is not surprising that a coal-mine soil contains a high level of Be. Small amounts of Be $\left(2-16 \mathrm{mg} \mathrm{L}^{-1}\right)$ in solution are toxic to plants, inhibiting seeds germination and reducing uptake of $\mathrm{Ca}$ and $\mathrm{Mg}$ by roots. Yet, only a negligible amount of the $\mathrm{Be}$ $\left(<0.01 \mathrm{mg} \mathrm{L}{ }^{-1}\right)$ was monitored in the mine soil solutions in the present study (elements with extremely low concentrations not shown in Tables 2 and 3), suggesting that Be in these mine soils was strongly bound to the soil matrix and would not be toxic to plant growth under normal conditions. Both soils contained rather high levels of $\mathrm{Sr}$, which is not uncommon because topsoils in the US normally contain 110-445 mg kg-1 $\mathrm{of} \mathrm{Sr}$ on average with the highest concentrations between 1,000-2,000 mg kg${ }^{-1}$ (Kabata-Pendias \& Pendias, 1984). Therefore, mine soils in the present study contained $\mathrm{Sr}$ levels within the $\mathrm{Sr}$ concentration range observed in the unmined soils. Stable Sr at levels present in the biosphere generally has no significant deleterious effects on humans, animals, or plants (Kabata-Pendias \& Pendias, 1984). High amounts of barium (Ba) are also found in the mine soils at concentrations of $\sim 1100 \mathrm{mg} \mathrm{kg}^{-1}$ but still within the concentration range $\left(10-3000 \mathrm{mg} \mathrm{kg}^{-1}\right)$ found in most soils in the US. Further, Ba is easily precipitated as sulfates and carbonates or is strongly adsorbed by clays, Mn, and P minerals (Kabata-Pendias \& Pendias, 1984). Thus, Ba concentrations in soil solutions were as low as $0.1 \mathrm{mg} \mathrm{L}^{-1}$ (Tables 2 and 3). In comparison, the maximum permissible level of Ba in drinking water is $2 \mathrm{mg} \mathrm{L}^{-1}$ (USEPA, 2009). Although the mine soils also contained relatively higher amounts of $\mathrm{Cu}, \mathrm{Cr}, \mathrm{Pb}, \mathrm{Se}$, and $\mathrm{Zn}$ compared with those in agricultural soils (Table 1), the levels are lower than those in soils impacted by metal ore mining and related processing operations (Dudka \& Adriano, 1997). This trend suggests that these soils affected by coal-mining-operations are relatively clean in comparison, and do not contain significant amounts of toxins. This conclusion is also supported by the fact that concentrations of heavy metals in the soil solutions are relatively low (Table 2 , metals with concentrations lower than the detection limits are not listed), and that the $\mathrm{Cu}$ and $\mathrm{Zn}$ levels are lower than the permissible levels for drinking water $(\mathrm{Cu}<1.0$ and $\mathrm{Zn}<5.0 \mathrm{mg}$ $\mathrm{L}^{-1}$ ) (USEPA, 2009). Concentrations of other macro-elements are found within ranges similar to those observed in coal refuse samples obtained from other states with coal mines (e.g., Virginia) (Daniels \& Stewart, 2000), suggesting that the coal refuse samples in the Midwest of USA have similar chemical compositions. Daniels and Stewart (2000) indicated that quartz was the major species in coal refuse with trivial amounts of clay minerals such as illite, kaolinite and chlorite. Yet, there is a notable difference in chemical properties of the two samples. For example, soil B contained higher Ca than soil A in both solid (Table 1) and solution phases (Tables 2 and 3), implying that the latter was more weathered (aged) and that more $\mathrm{Ca}$ ions might have been leached by rainfall from soil B than from the former. For similar reasons, aqueous concentrations of other macro-elements are either lower or similar in the solution of soil A than those of soil B. In addition, soil B seemingly contains a higher coal fraction than soil A because the C concentration is approximately 24 times higher in soil B than in soil A. Overall, the elemental analyses (Tables 1, 2, and 3) indicate that these two mine soils do not contain significant amounts of contaminants (especially in the soil solutions) and could possibly be used as growing media for biomass production and for soil $\mathrm{C}$ sequestration.

Table 1. Mine soil properties and contents of selected elements before amendment

\begin{tabular}{|c|c|c|c|c|c|c|c|c|c|c|c|c|c|c|c|c|c|c|c|c|c|}
\hline \multirow{2}{*}{$\begin{array}{c}\text { Mine } \\
\text { soil }\end{array}$} & \multirow{2}{*}{$\mathrm{pH}$} & \multirow{2}{*}{$\begin{array}{l}\text { EC - }(\mu S \\
\mathrm{cm}-1 .)\end{array}$} & \multirow{2}{*}{$\begin{array}{l}\text { Dry } \\
\text { color }\end{array}$} & \multicolumn{8}{|c|}{ Macro- elements $\left(\mathrm{g} \mathrm{kg}^{-1}\right)$} & \multicolumn{10}{|c|}{ Trace-elements. (mg $\mathrm{kg}^{-1}$ ) } \\
\hline & & & & $\mathrm{Ca}$ & $\mathrm{Mg}$ & $\mathrm{K}$ & $\mathrm{Fe}$ & $\mathrm{P}$ & s & $\mathrm{N}$ & c & As & B & $\mathrm{Ba}$ & $\mathrm{Be}$ & $\mathrm{Cu}$ & $\mathrm{Cr}$ & $\mathrm{Ph}$ & $\mathrm{Se}$ & $\mathrm{St}$ & $\mathrm{zn}$ \\
\hline Soll $\mathrm{A}$ & $4.66 \mathrm{~s}$ & $102.2 b$ & $\begin{array}{c}7.5 \mathrm{Y} \cdot 72 \\
\text { pink-ish } \\
\text { gray }\end{array}$ & $0.4 b$ & $2.5 \mathrm{a}$ & $17.8 \mathrm{~b}$ & $49.0 \mathrm{a}$ & 0.60 & $15.3 \mathbf{a}$ & 0.26 & $2.8 b$ & $57.2 \mathrm{a}$ & $15.9 \mathbf{3}$ & $1120.8 \mathrm{~s}$ & $13.6 \mathrm{~s}$ & $134.9 \mathrm{~g}$ & 34.36 & $33.3 \mathbf{3}$ & $11.3 \mathrm{~s}$ & $1253.5 \mathrm{~s}$ & $35.0 \mathrm{a}$ \\
\hline Soll. B & $3.80 \mathrm{~b}$ & 297.72 & $\begin{array}{c}5 Y 5 / 0 . \\
\text { gray }\end{array}$ & $4.2 \mathrm{a}$ & $3.0 \mathrm{~b}$ & $19.9 \mathrm{~g}$ & $35.8 \mathrm{~b}$ & $0.9 \mathrm{a}$ & $13.6 \mathrm{a}$ & $2.1 \mathrm{z}$ & $65.8 \mathrm{a}$ & $35.6 \mathrm{~b}$ & 26.83 & $1147.9_{2}$ & $s . s b$ & $33.8 \mathrm{~b}$ & $49.6 \mathrm{a}$ & $27.0 \mathrm{a}$ & 11.03 & 1110.72 & $13.7 b$ \\
\hline $\begin{array}{l}\text { USA } \\
\text { sollst }\end{array}$ & & & & & & & & & & & & 0.1 .69 & $20-55$ & $\begin{array}{c}10 . \\
3000\end{array}$ & 1.6 & 14.29 & 54 & 20 & $<4.0$ & $\begin{array}{l}110 . \\
445\end{array}$ & $17-25$ \\
\hline F-test: & $308.42^{*}$ & $20.31^{*}$ & & $28.14^{*}$ & $1.48^{\circ}$ & $8.89^{\circ}$ & $18.05^{*}$ & $22.54^{*}$ & $1.48 \mathrm{~ns}$ & $240.67^{*}$ & $193.36^{*}$ & $79.44^{*}$ & $69.74 \mathrm{~ns}$ & $0.23 \mathrm{~ns}$ & $33.24^{*}$ & $11.96^{*}$ & $42.11^{*}$ & $4.45 \mathrm{~ns}$ & $0.01 \mathrm{~ns}$ & $1.40 \mathrm{~ns}$ & $77.41^{*}$ \\
\hline $\mathrm{CV} \cdot(\%)$ & 1.4 & 21.6 & & 38.1 & 5.6 & 4.7 & 9.7 & 8.7 & 11.7 & 13.6 & 16.2 & 6.4 & 7.5 & 6.1 & 9.3 & 30.4 & 6.9 & 12.2 & 23.3 & 12.5 & 12.2 \\
\hline
\end{tabular}


Table 2. Concentrations of selected elements in 1:4 DI water solutions of soil A and mixtures of soil A and amendments after 35-d incubation

\begin{tabular}{|c|c|c|c|c|c|c|c|c|c|c|c|c|}
\hline \multirow{2}{*}{ Soil'A or Soil $\mathrm{A}$ /amendment mixtures } & \multicolumn{7}{|c|}{ Macro-elements $\left(\mathrm{mg} \cdot \mathrm{L}^{-1}\right)$} & \multicolumn{5}{|c|}{ Micro-elements $\left(\mathrm{mg} \cdot \mathrm{L}^{-1}\right)$} \\
\hline & $\mathrm{Ca}$ & $\mathrm{Mg}$ & $\mathrm{K}$ & s & $\mathrm{Na}$ & Al & $\mathrm{Mn}$ & B & $\mathrm{Ba}$ & $\mathrm{Cu}$ & $\mathrm{Sr}$ & $\mathrm{Zn}$ \\
\hline Mine soil $\mathrm{A}$ & $4.7 \mathrm{c}$ & $0.7 \mathrm{~b}$ & $4.3 \mathrm{~b}$ & $8.7 \mathrm{~b}$ & $7.0 \mathrm{c}$ & $0.5 \mathrm{ab}$ & $0.17 \mathrm{~ns}$ & $4.5 n s$ & $0.12 \mathrm{a}$ & $0.01 \mathrm{a}$ & $0.82 a$ & $0.05 b$ \\
\hline $10 \%$ big zeolite- & $7.3 \mathrm{c}$ & $0.9 \mathrm{~b}$ & $3.0 \mathrm{c}$ & $13.3 \mathrm{~b}$ & $10.3 b$ & $0.6 \mathrm{a}$ & $0.08 \mathrm{~ns}$ & $4.3 \mathrm{~ns}$ & $0.08 \mathrm{ab}$ & $0.01 \mathrm{a}$ & $0.41 \mathrm{c}$ & $0.05 b$ \\
\hline $10 \%$ zeolite small & $4.8 \mathrm{c}$ & 0.76 & $5.4 \mathrm{a}$ & $15.2 \mathrm{~b}$ & $15.5 \mathrm{a}$ & $0.4 \mathrm{~b}$ & $0.13 \mathrm{~ns}$ & $3.7 \mathrm{~ns}$ & $0.06 \mathrm{c}$ & $0.01 \mathrm{a}$ & $0.22 \mathrm{~d}$ & $0.04 b$ \\
\hline $10 \% \cdot F G D$ & $145.3 \mathrm{a}$ & $4.4 \mathrm{a}$ & $1.5 \mathrm{~d}$ & $166.7 \mathrm{a}$ & $6.5 \mathrm{c}$ & $0.3 \mathrm{~b}$ & $0.3 \mathrm{~ns}$ & $4.6 \mathrm{~ns}$ & $0.06 c$ & $o b$ & $0.24 d$ & $0.02 \mathrm{~b}$ \\
\hline $10 \%$ flyash & $14.8 \mathrm{~b}$ & $1.1 \mathrm{~b}$ & $1.1 \mathrm{e}$ & $15.6 \mathrm{~b}$ & $8.8 b c$ & $0.6 \mathrm{a}$ & $0.2 \mathrm{~ns}$ & $6.3 \mathrm{~ns}$ & $0.09 \mathrm{~b}$ & $\mathrm{ob}$ & $0.67 \mathrm{~b}$ & $0.03 b$ \\
\hline $10 \%$ biosolid & $10.0 \mathrm{~b}$ & $1.6 \mathrm{ab}$ & $1.8 \mathrm{~d}$ & $17.7 \mathrm{~b}$ & $6.7 \mathrm{c}$ & $0.4 b$ & $0.2 \mathrm{~ns}$ & 4. ons & $0.08 b$ & $0.01 \mathrm{a}$ & $0.41 \mathrm{c}$ & $0.15 \mathrm{a}$ \\
\hline Representative soils & $30-300$ & $5-50$ & $1-10$ & $50-500$ & $0.5-5$ & $<0.01$ & & & & $0.03-0.3$ & & $<00.005$ \\
\hline F-test & $152.51^{*}$ & $32.05^{*}$ & $203.89^{*}$ & $75.55^{*}$ & $35.51^{*}$ & $7.38^{*}$ & $2.44 \mathrm{~ns}$ & $4.00 \mathrm{~ns}$ & $124.38^{*}$ & $7.31^{*}$ & $780.21^{*}$ & $5.31^{*}$ \\
\hline $\mathrm{CV} \cdot(\%)$ & 20.6 & 23.0 & 62.0 & 25.7 & 9.0 & 14.8 & 37.3 & 14.0 & 3.5 & 36.2 & 2.6 & 52.1 \\
\hline
\end{tabular}

Table 3. Concentrations of selected elements in 1:4 water solutions of soil B and mixtures of soil B and amendments after 35-d incubation

\begin{tabular}{|c|c|c|c|c|c|c|c|c|c|c|c|c|}
\hline \multirow{2}{*}{$\begin{array}{c}\text { Soil B-or soil } \\
\text { B amendment mixture }\end{array}$} & \multicolumn{7}{|c|}{ Macro-elements-(mg L-1) } & \multicolumn{5}{|c|}{ Micro-elements $\left(\mathrm{mg} \mathrm{LL}^{-1}\right)$} \\
\hline & $\mathrm{Ca}_{\mathrm{a}}$ & $\mathrm{Mg}$ & $\mathrm{K}$ & s & $\mathrm{N}_{3}$ & $\mathrm{Al}$ & $\mathrm{Mn}$ & B & $\mathrm{Ba}$ & $\mathrm{Cu}$ & $\mathrm{St}$ & $\mathrm{Zn}$ \\
\hline Mine soil B only & $342.7 b$ & $0.95 d$ & $1.97 \mathrm{c}$ & $292.4 \mathrm{~b}$ & $5.8 \mathrm{c}$ & $3.13 \mathrm{a}$ & $0.63 \mathrm{~b}$ & $3.4 b$ & $0.10 \mathrm{a}$ & $0.04 a$ & $0.46 a$ & 0.176 \\
\hline $10 \%$ coarse zeolite & $79.7 \mathrm{~d}$ & $1.96 \mathrm{~cd}$ & $6.10 \mathrm{~b}$ & $\$ 2.3 \mathrm{~d}$ & $13.5 \mathrm{~b}$ & $0.35 \mathrm{c}$ & $0.38 \mathrm{c}$ & 3.86 & $0.04 b$ & $0.01 \mathrm{c}$ & $0.13 d$ & 0.066 \\
\hline $10 \%$-fine zeolite & $91.7 \mathrm{~cd}$ & $2.79 \mathrm{c}$ & $10.35 \mathrm{a}$ & $98.4 \mathrm{~d}$ & $22.4 \mathrm{a}$ & $0.46 \mathrm{bc}$ & $0.57 \mathrm{~b}$ & $4.8 b$ & $0.04 \mathrm{~b}$ & $0.02 \mathrm{~b}$ & $0.15 \mathrm{~d}$ & $0.15 \mathrm{~b}$ \\
\hline $10 \%$ FGD & $410.9_{3}$ & $6.39 \mathrm{a}$ & $2.53 \mathrm{c}$ & $467.2 \mathrm{a}$ & $7.6 \mathrm{c}$ & $0.00 \mathrm{e}$ & $0.28 \mathrm{c}$ & $4.7 \mathrm{~b}$ & $0.11 \mathrm{a}$ & $0.00 \mathrm{c}$ & $0.25 \mathrm{~b}$ & $0.02 b$ \\
\hline $10 \%$ - Alvash & $151.7 \mathrm{c}$ & $2.78 \mathrm{c}$ & $0.23 \mathrm{~d}$ & $141.1 \mathrm{c}$ & $8.1 \mathrm{c}$ & $0.70 \mathrm{~b}$ & $0.62 \mathrm{~b}$ & $7.2 \mathrm{~s}$ & $0.05 b$ & $0.00 \mathrm{c}$ & 0.483 & 0.096 \\
\hline $10 \%$ biosslid & $118.6 c d$ & $5.04 \mathrm{~b}$ & $0.43 \mathrm{~d}$ & $128.8 \mathrm{c}$ & $7.5 \mathrm{c}$ & $0.19 \mathrm{~d}$ & $0.77 \mathrm{a}$ & $4.2 \mathrm{~b}$ & 0.056 & $0.00 \mathrm{c}$ & $0.17 \mathrm{c}$ & $0.54 \mathrm{a}$ \\
\hline Representative soils ${ }^{\dagger}$ & $30-300$ & $5-50$ & $1-10$ & $50-500$ & $0.5-5$ & $<0.01$ & & & $0.03 \cdot 0.3$ & & $<.00 .005$ & \\
\hline F-test: & $180.21^{*}$ & $106.26^{*}$ & $291.42^{*}$ & $224.80^{*}$ & $93.47^{*}$ & $740.20^{*}$ & $21.55^{*}$ & $0.58^{*}$ & $106.16^{*}$ & $50.25^{*}$ & $310.02^{*}$ & $19.09^{*}$ \\
\hline $\mathrm{CX}(\%)$ & 7.5 & 8.3 & 9.1 & 7.0 & 8.5 & 7.5 & 10.0 & 223.8 & 6.1 & $2 s .1$ & 4.7 & 35.7 \\
\hline
\end{tabular}

The data in Tables 2 and 3 show the changes in soil solution chemistry by application of $10 \%$ of each amendment. Application of flyash increased the concentration of boron in the soil A solution by 1.4 times, from 4.5 to $6.3 \mathrm{mg} \mathrm{L}^{-1}$, and in the soil B solution by more than 2 times, from 3.4 to $7.2 \mathrm{mg} \mathrm{L}^{-1}$. Application of fly-ash also increased $\mathrm{Sr}$ concentration in the soil A solution by 2 times but did not affect it in the solution of soil B. Application of the biosolids increased the $\mathrm{Zn}$ concentrations by 3 times (from 0.05 to $0.15 \mathrm{mg} \mathrm{L}^{-1}$ in A solution and from 0.17 to $0.54 \mathrm{mg} \mathrm{L}^{-1}$ in $\mathrm{B}$ solution) in the soil solutions, indicating possible $\mathrm{Zn}$ contamination by biosolids application. Otherwise, use of these amendments did not significantly increase the contaminant levels in the solution of either soil, suggesting that these amendments are relatively safe at $10 \%$ application rate as far as any environmental contamination is concerned. Moreover, use of all these amendments greatly reduced the high concentration of $\mathrm{Al}\left(3.13 \mathrm{mg} \mathrm{L}^{-1}\right)$ in soil B solution, showing that these materials might ameliorate $\mathrm{Al}$ toxicity (e.g. in acidic soils) to plants. In addition, application of these amendments increased plant nutrient levels in the solution albeit to different extents. Specifically, FGD application increased the concentrations of $\mathrm{Ca}$, $\mathrm{K}$, and $\mathrm{S}$ by 30, 6.3, and 19 times, respectively, in soil A solution. Because soil B itself contained high amounts of $\mathrm{Ca}, \mathrm{Mg}$, and $\mathrm{S}$, levels of these elements was not increased as significant by the amendment: $\mathrm{Ca}$ increased by 1.2 times, $\mathrm{Mg}$ by 6.7 times, and $\mathrm{S}$ by 1.6 times. This trend shows that FGD is also an ideal source of plant nutrients for these mine soils. 
Table 4. Amendment properties and contents of selected elements

\begin{tabular}{|c|c|c|c|c|c|c|c|c|c|c|c|c|c|c|c|c|c|c|c|}
\hline \multirow{2}{*}{$\begin{array}{l}\text { Amend } \\
\text {-meat }\end{array}$} & \multirow{2}{*}{$\begin{array}{l}\mathrm{pH} \text { in } \\
\text { 1:4 DI } \\
\text { water }\end{array}$} & \multirow{2}{*}{$\begin{array}{l}\text { EC in } 1: 4 \\
\text { DI water } \\
\text { (uS: } \mathrm{cm}-1)\end{array}$} & \multirow{2}{*}{$\begin{array}{c}\text { Particle } \\
\text { size (mm) }\end{array}$} & \multicolumn{5}{|c|}{ Macro-elements $\left(\mathrm{g} \mathrm{kg}^{-1}\right)$} & \multirow[b]{2}{*}{$s$} & \multirow[b]{2}{*}{ As } & \multirow[b]{2}{*}{ B } & \multirow[b]{2}{*}{$\mathrm{Ba}$} & \multirow[b]{2}{*}{$\mathrm{Be}$} & \multicolumn{6}{|c|}{ Micro-elements (mg. $\left.\mathrm{kg}^{-1}\right)$} \\
\hline & & & & $\mathrm{Ca}$ & $\mathrm{Mg}$ & $\mathrm{K}$ & $\mathrm{Fe}$ & $P$ & & & & & & $\mathrm{Cd}$ & $\mathrm{Cu}$ & $\mathrm{Cr}$ & $\mathrm{Pl}$ & st & $\mathrm{zn}$ \\
\hline $\begin{array}{l}\text { Coarse } \\
\text { zeolite }\end{array}$ & 9.56 & $46.5 \mathrm{c}$ & $1.4 \sim 0.4$ & $21.3 c$ & $6.37 \mathrm{a}$ & $7.30 \mathrm{a}$ & $9.09 \mathrm{~d}$ & $0.16 \mathrm{c}$ & $0.51 \mathrm{~d}$ & $4.6 \mathrm{~d}$ & od & 222.16 & $4.40 \mathrm{c}$ & $0.31 \mathrm{~d}$ & $5.40 \mathrm{~d}$ & $3.10 \mathrm{~d}$ & $31.00 \mathrm{bc}$ & 2776 & $41.50 \mathrm{c}$ \\
\hline $\begin{array}{l}\text { Fine } \\
\text { zeolite }\end{array}$ & $8.6 \mathrm{c}$ & $106.1 \mathrm{c}$ & $<0.04$ & $18.56 \mathrm{c}$ & $5.11 \mathrm{a}$ & $5.11 \mathrm{~b}$ & $7.90 \mathrm{~d}$ & $0.11 \mathrm{c}$ & $0.49 \mathrm{~d}$ & $2.7 \mathrm{~d}$ & Od & $137.7 \mathrm{bc}$ & $3.90 \mathrm{c}$ & $0.32 \mathrm{~d}$ & $6.70 \mathrm{sd}$ & $4.90 \mathrm{~d}$ & $13.30 \mathrm{c}$ & $248.8 \mathrm{c}$ & $50.2 \mathrm{c}$ \\
\hline FGD & $11.2 \mathrm{a}$ & 8276 & $<2$ & $134.74 \mathrm{a}$ & $4.12 \mathrm{~b}$ & $2.14 d$ & 20.016 & $0.20 \mathrm{c}$ & $84.21 \mathrm{~s}$ & 34.16 & 138.06 & $88.0 \mathrm{c}$ & 5.986 & $1.01 \mathrm{c}$ & $14.58 \mathrm{c}$ & $18.12 \mathrm{c}$ & $7.62 \mathrm{c}$ & $178.1 \mathrm{~d}$ & $40.9 c$ \\
\hline Alvash & $7.6 \mathrm{~d}$ & 8936 & $<0.3$. & $9.53 \mathrm{c}$ & $1.59 \mathrm{c}$ & $3.64 \mathrm{c}$ & $89.22 \mathrm{z}$ & 1.016 & $3.04 \mathrm{c}$ & $158.3 \mathrm{a}$ & $304.3 \mathrm{a}$ & $155.6 \mathrm{bc}$ & $28.57 \mathrm{a}$ & $4.27 \mathrm{a}$ & 63.876 & 75.162 & 41.386 & $134.61 \mathrm{a}$ & 340.76 \\
\hline $\begin{array}{l}\text { Bio- } \\
\text { solid }\end{array}$ & $7.8 \mathrm{~d}$ & 17633 & lump & $4.10 \mathrm{~b}$ & $6.88 \mathrm{a}$ & $2.66 \mathrm{~d}$ & $13.82 \mathrm{c}$ & $20.00 \mathrm{a}$ & 14.496 & $9.1 \mathrm{c}$ & $34.2 \mathrm{c}$ & $378.3 \mathrm{a}$ & $3.00 \mathrm{~d}$ & 3.316 & $468.90 \mathrm{a}$ & 55.306 & $78.80 \mathrm{z}$ & $256.9 \mathrm{c}$ & $2330.5 \mathrm{a}$ \\
\hline F. Test' & $\begin{array}{c}87.09 \\
*\end{array}$ & $241.05^{*}$ & & $310.38^{*}$ & $267.61^{*}$ & $104.93^{*}$ & $\begin{array}{c}3260.84 \\
\times\end{array}$ & $\begin{array}{c}22160.8 \\
3^{*}\end{array}$ & $\begin{array}{c}5232.00 \\
*\end{array}$ & $\begin{array}{c}9015.48 \\
*\end{array}$ & $\begin{array}{c}2015.46 \\
\times\end{array}$ & $41.46^{*}$ & $\begin{array}{c}3887.34 \\
\times\end{array}$ & $\begin{array}{c}2146.35 \\
*\end{array}$ & $\begin{array}{c}11381.3 \\
3^{*}\end{array}$ & $358.04^{*}$ & $30.66^{*}$ & $209.46^{*}$ & $\begin{array}{c}20049.5 \\
5^{*}\end{array}$ \\
\hline $\mathrm{CX}(\%)$ & 3.1 & 10.7 & & 11.2 & 4.6 & 8.5 & 3.7 & 2.4 & 4.2 & 2.9 & 7.0 & 15.4 & 3.3 & 3.7 & 2.9 & 9.5 & 25.7 & 2.7 & 2.4 \\
\hline
\end{tabular}

The data in Table 4 exhibit the chemical composition of the amendments used in this study. Zeolite, a natural mineral, generally contained low amounts of impurities and thus had low EC. In comparison, the industrial wastes (flyash, FGD, and the biosolids) contained relatively high amount of nutrients ( $\mathrm{Ca}, \mathrm{K}$, and $\mathrm{P}$ ) as well as heavy metals $(\mathrm{Cu}, \mathrm{Cr}$, and $\mathrm{Pb})$. Specifically, FGD contained the highest levels of $\mathrm{Ca}$ and $\mathrm{S}$, and was thus able to adequately supply both nutrients to the plants grown in soils where $\mathrm{Ca}$ and $\mathrm{S}$ were deficient (also see Table 2 and 3 for soil solution chemistry). Flyash included the highest amounts of Fe, As, and B and significant amounts of $\mathrm{Cu}, \mathrm{Cr}, \mathrm{Pb}$, and $\mathrm{Zn}$, which could become a potential contamination source of heavy metals when environmental conditions changed (e.g. soil became more acidic) or when high rates of flyash were applied. However, significant leaching of heavy metals was not found in the soil solutions with $10 \%$ flyash application (Tables 2 and 3). The biosolids sample contained the highest amount of nutrient $\mathrm{P}$ and significant amounts of $\mathrm{Fe}$ and $\mathrm{S}$, but also contained the highest concentrations of several contaminants: $\mathrm{Zn}, \mathrm{Cu}$, and $\mathrm{Pb}$ and a significant amount of $\mathrm{Cr}$. All of the industrial wastes had high EC, showing those amendments could increase salt concentration in soils and negatively affect vegetation growth. However, all these materials also exhibited alkaline properties ( $\mathrm{pH}$ value > 7), confirming that application of these amendments could neutralize the mine soil acidity.

\subsection{Changes of Mine Soil pH With Amendments}

An optimal vegetation growth is mostly observed in soils at neutral $\mathrm{pH}$. Low soil $\mathrm{pH}$ often increases the solubility of toxic metals such as $\mathrm{Al}^{3+}$ and $\mathrm{Mn}^{2+}$ in the soil solution and these metals not only impair the physiological functions of plants but also interfere with the uptake of other nutrient elements (e.g., $\mathrm{Ca}, \mathrm{Mg}$, and $\mathrm{P}$ )(Sambou et al., 2010). Toxicity of $\mathrm{Al}$ is the most widespread problem in soils with the $\mathrm{pH}$ of $<5.5$. The data in Table 3 show a high concentration of $3.13 \mathrm{mg} \mathrm{L}^{-1}$ of Al in soil B solution. In general, Al starts to restrict or completely stop root growth at solution concentrations of as low as $1 \mathrm{mg} \mathrm{L}^{-1}$ (Bohn et al., 1979). Low pH also retards beneficial microbial activities such as the biological N fixation (BNF). Since significantly high levels of typical phytotoxic elements (e.g. heavy metals, boron, or selenium) were not observed in the soils or in the solutions (Tables 1, 2, and 3) in this study, low soil $\mathrm{pH}$ is most likely the primary factor inhibiting vegetation establishment in these soils. Therefore, increasing mine soil $\mathrm{pH}$ through uses of suitable amendments is one of the major research objectives for improving the mine soil quality.

The data in Figure 1 show that about 15-20 days were needed for the amendments to reach reaction equilibrium in both soils as far as the soil $\mathrm{pH}$ is concerned, implying relatively slow neutralization reactions in the solid phase. Among all amendments, FGD exhibited the highest neutralization capacity to increase the mine soil $\mathrm{pH}$, from 4.66 to a final value of $\sim 5.70$ for soil A and 3.80 to $\sim 6.60$ for soil B. The highest neutralization capacity of FGD is attributed to the residual level of alkaline $\mathrm{CaO}$ and $\mathrm{Ca}(\mathrm{OH})_{2}$ (Crews et al., 1998; Clark et al., 2001; Kost et al., 2005). This trend is also reflected by the highest $\mathrm{pH}$ value of the FGD ( $\mathrm{pH}=11.2$, Table 4). During the duration of the experiment (about 35 d), the FGD neutralization curve of soil A (Figure 1, top) shows an initial rapid increase in $\mathrm{pH}$ to the maxima of 6.26 , then a gradual decrease by a total of 0.5 unit, and a final stabilization at $\sim 5.70$. The fluctuations in $\mathrm{pH}$ could be explained by the fact that there was a small portion of acid slowly released when the soil was in contact with air for a longer period, allowing some residual $\mathrm{S}$ to be oxidized under laboratory conditions. Similar trends have also been observed for other amendment materials. Although soil B initially had a lower $\mathrm{pH}$ than soil A, application of FGD increased the $\mathrm{pH}$ of soil $\mathrm{B}$ to 6.6 , a 0.9 unit higher than that of soil A. In addition, the decline in $\mathrm{pH}$ from an initial maximum was not as apparent for soil $\mathrm{B}$ during the whole neutralization process (Figure 1, bottom). This trend is most likely attributed to more antecedent concentration of un-oxidized sulfur (potential acidity) in soil A $\left(15.3 \mathrm{~g} \mathrm{~kg}^{-1}\right)$ than soil B $\left(13.6 \mathrm{~g} \mathrm{~kg}^{-1}\right)$. 

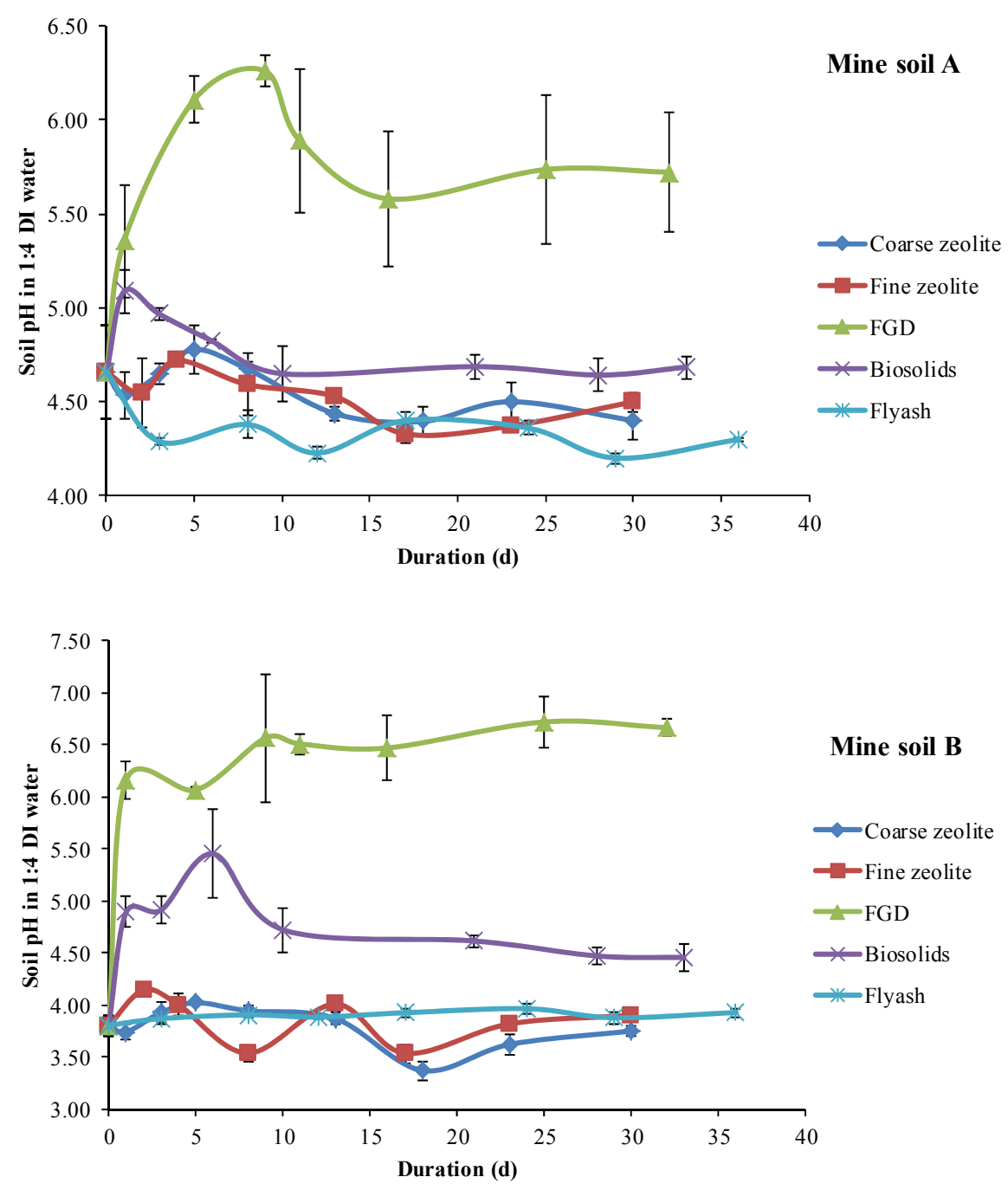

Figure 1. Effects of amendments on pH of soil A (top) and soil B (bottom). Error bars represent standard deviation

Biosolids contained some alkalinity which was added to improve the efficacy of the sludge digestion and ensure proper disposal of the waste (USEPA, 2000). However, the neutralization capacity of the solids was limited compared with that of FGD. Thus, biosolids did not significantly enhance the final $\mathrm{pH}$ of soil A during the 35-d period. Although pH of soil A increased initially from 4.66 to 5.09 in $1 \mathrm{~d}$ by the amendment, it decreased afterwards and stabilized at 4.68 close to the antecedent value (4.66). Application of biosolids increased the $\mathrm{pH}$ of soil B to 5.45 in first $6 \mathrm{~d}$, but it eventually stabilized at 4.50 . Neither the application of coarse zeolite nor that of the fine zeolite increased soil $\mathrm{pH}$ for either soil, although slight increase in $\mathrm{pH}$ was initially observed. Application of flyash even decreased $\mathrm{pH}$ of soil A by 0.36 , but slightly increased that of soil B by 0.2 unit, indicating that flyash used in this study was not a good amendment for amelioration of soil $\mathrm{pH}$.

In summary, application of FGD at $10 \%(\mathrm{w} / \mathrm{w})$ significantly increased soil $\mathrm{pH}$ by $1 \sim 2.9$ units. In comparison, application of biosolids increased $\mathrm{pH}$ of soil $\mathrm{B}$ by 0.7 but did not significantly change that of soil A. Amendments of coarse zeolite, fine zeolite, and flyash did not significantly affect the final $\mathrm{pH}$ for either soil at $10 \%$ application rate. It took more than $10 \mathrm{~d}$ for both soils to attain a relatively stable $\mathrm{pH}$ after amendments. Application of all amendments initially increased $\mathrm{pH}$ of both soils for a short period followed by a decrease and eventual stabilization over the longer period. This pattern in soil $\mathrm{pH}$ indicates the presence of some un-oxidized $\mathrm{S}$ (potential acidity) in these mine soils and a slow release of the acid over time. This trend also suggests that re-acidification of the amended-mine soil could occur due to the slow release of the acid by the remaining un-oxidized $\mathrm{S}$. Therefore, a frequent monitoring of soil $\mathrm{pH}$ is recommended even after the soil $\mathrm{pH}$ is increased to a desired level, and further treatment (applying more materials in a few months) might be needed. 


\subsection{Lettuce Seed Germination Test}

Chemical analyses of soils and soil solutions indicated any amendment-induced changes in soil chemical properties. The purpose of germination test was to provide direct evidence on plant response to mine soils with and without the amendments. The 5-d germination percentage and shoot length were used to evaluate the amendment-caused changes in soil quality.
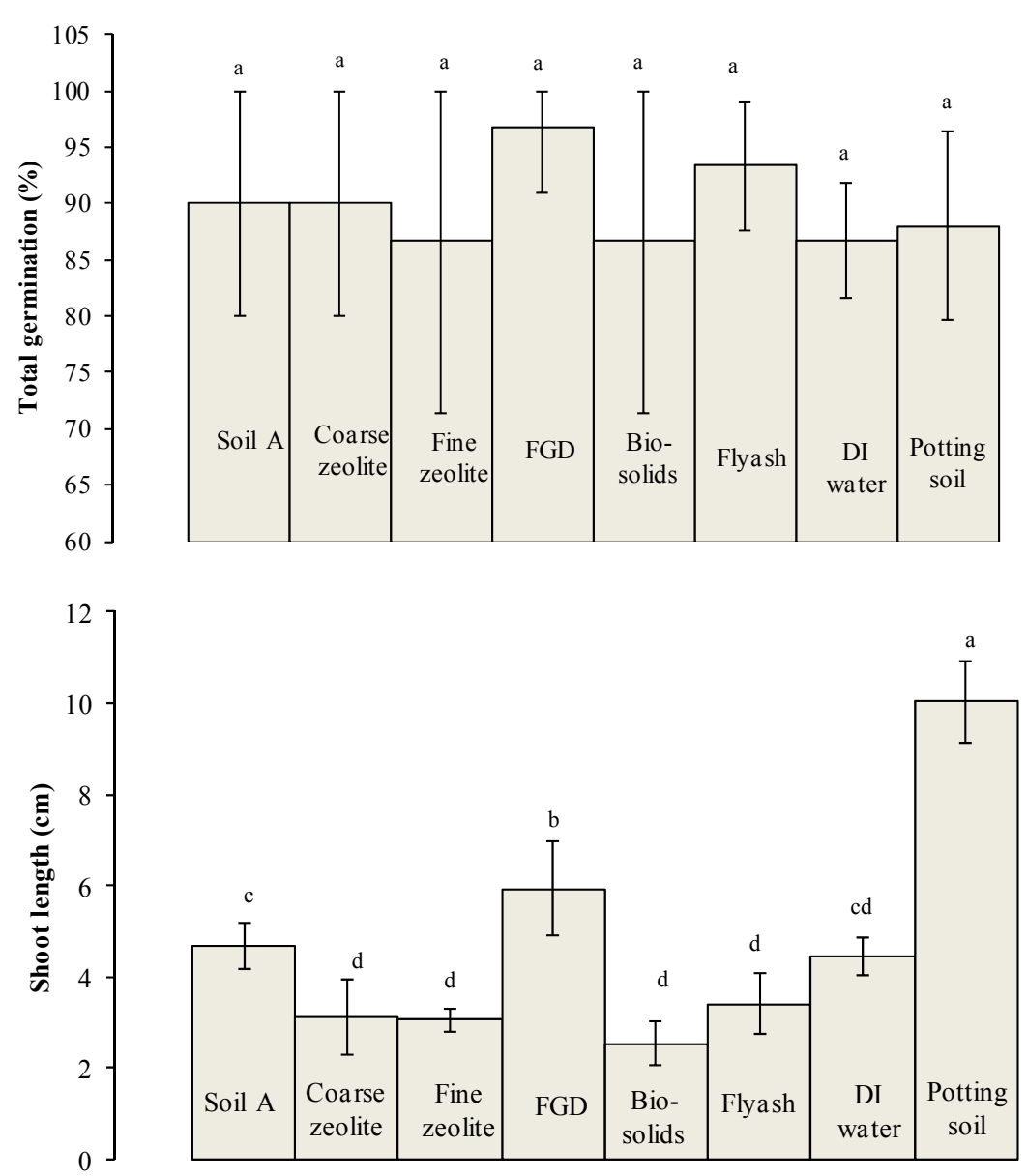

Figure 2. Effects of amendments on lettuce seed germination in 1:4 soil A solution: germination percentage (top) and shoot length (bottom). Error bars represent standard deviation. Values with different lowercase letters are significantly different by Tukey test $(p<0.05)$

The data in Figure 2 show a 90\% germination percentage of lettuce seeds and a $4.7-\mathrm{cm}$ average shoot length of the germinated seeds in the unamended-soil A solution. The percentage is close to that in DI water or in the potting soil solution and the shoot length is also close to that in the DI water $(4.4 \mathrm{~cm})$ but only half of that observed in the potting soil $(10.0 \mathrm{~cm})$. These data suggest that soil A did not contain significant amounts of toxins, and that the soil solution was as mild as the DI water. However, the mine soil may not contain adequate amount of plant nutrients for the lettuce sprouts to grow. Thus, the shoot length is much shorter than that in the fertile potting soil. Among the 5 amendments, only FGD exhibited a significantly positive effect on both the germination and the shoot elongation rates. Specifically, using FGD increased the seed germination percentage in soil A solution from $90 \%$ to $97 \%$ (although not statistically significant) and the shoot length to $5.9 \mathrm{~cm}$. In comparison with DI water and potting soil, lettuce seedlings grew better in solution of the FGD-amended soil than in the DI water $(4.4 \mathrm{~cm})$ but not as well as in the potting soil solution $(10.0 \mathrm{~cm})$, suggesting that FGD may contain some plant nutrients (Ca and $\mathrm{S}$ ), but not other important plant nutrients. In contrast, solutions from soils amended with zeolites, flyash, and biosolids did not increase and in some cases or even inhibited lettuce seed germination and reduced the shoot length in comparison with that under un-amended soil A. Thus, those 
materials had some adverse negative effects on seed germination, probably because of high concentration of salts (e.g., $\mathrm{Na}$ ) in the solution.
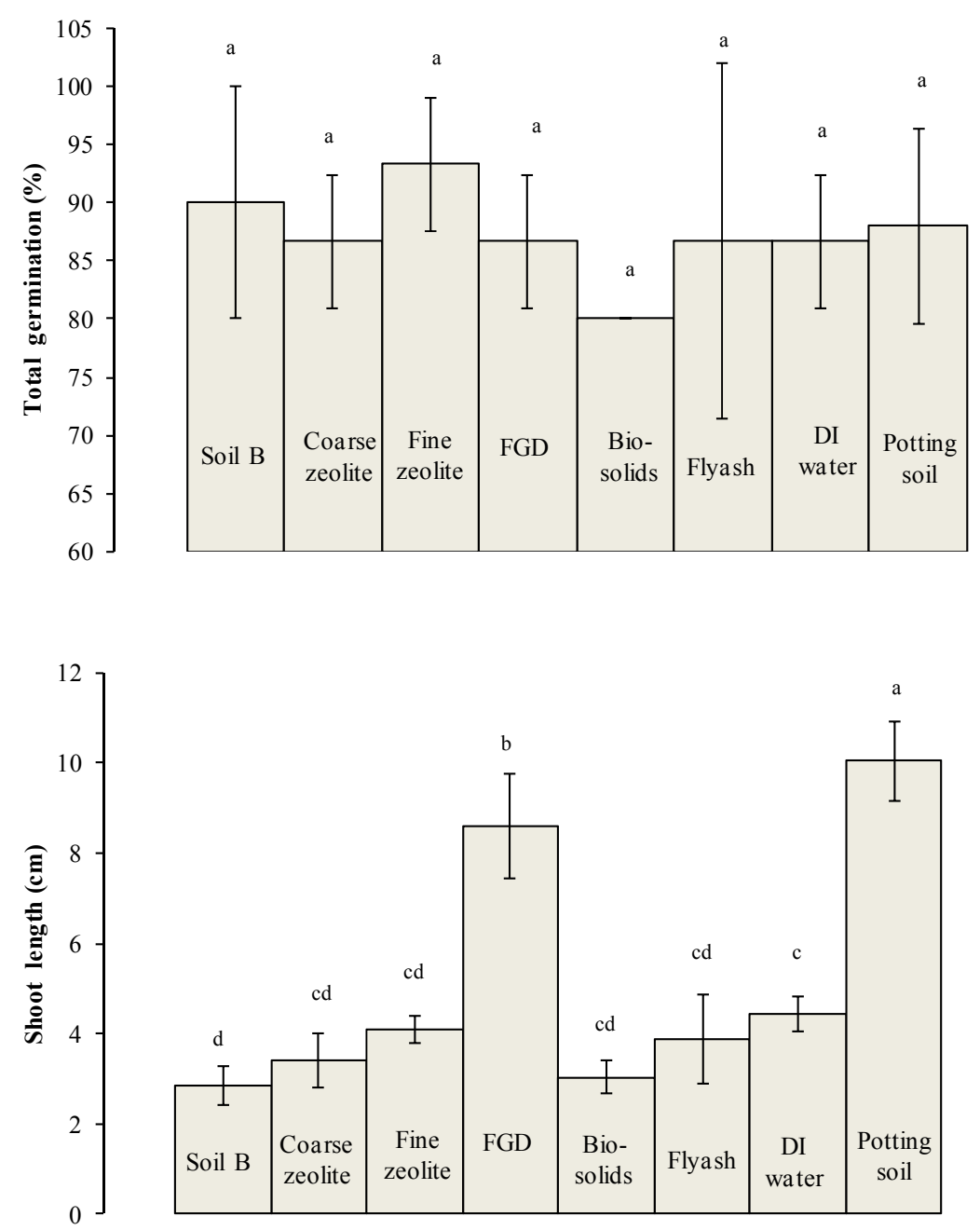

Figure 3. Effects of amendments on lettuce seed germination in 1:4 soil B solution: germination percentage (top) and shoot length (bottom). Error bars represent standard deviation. Values with lowercase letters are significantly different by Tukey test $(p<0.05)$

In contrast, these amendments enhanced growth of lettuce seedlings to varying extents in solutions of soil B (Figure 3) although the germinations were not significantly improved compared with that of the un-amended soil solution (Figure 3a). For example, coarse zeolite and biosolids slightly increased the shoot length to 3.4 and 3.0 $\mathrm{cm}$, respectively, from $2.9 \mathrm{~cm}$ in the un-amended soil solution. The germinations were $87 \%$ and $80 \%$, respectively, for each case, compared with $90 \%$ in the solution from un-amended soil B. Similarly, use of fine zeolite and flyash improved the shoot length to 3.4 and $3.9 \mathrm{~cm}$ and germination rates were $93 \%$ and $87 \%$, respectively. Seedling growth of $2.9 \mathrm{~cm}$ in solution B was shorter than that of $4.7 \mathrm{~cm}$ in solution A or $4.4 \mathrm{~cm}$ in DI water, and much shorter than that of $10.0 \mathrm{~cm}$ in the potting soil solution. These results indicate that soil B had more adverse effect on lettuce growth than soil A, probably because of higher acidity in the former rather than because of any toxic element. Therefore, use of amendments increased the lettuce growth by neutralizing soil acidity albeit to a varying degree. The highest positive effect of amendment was observed for FGD on shoot growth in soil B. Application of FGD enhanced the shoot growth from $2.9 \mathrm{~cm}$ to $8.6 \mathrm{~cm}$ in comparison with 4.4 $\mathrm{cm}$ in DI water and $10.0 \mathrm{~cm}$ in potting soil, showing that FGD not only effectively reduced soil acidity but also supplied some nutrients into the soil solution, benefiting seedling growth. Moreover, it was reported that enhanced $\mathrm{SO}_{4}{ }^{2-}$ concentration in soil solution by FGD amendment could reduce the Al toxicity to plants by forming $\mathrm{AlSO}_{4}{ }^{+}$complexes (Chen et al., 2001; Illera et al., 2004). 
As discussed earlier, low soil $\mathrm{pH}$ (soil acidity) is the major factor inhibiting plant growth and is thus the principal determinant of the quality of these two mine soils. Therefore, mine soil B with lower $\mathrm{pH}$ was of poorer quality than soil A with a relatively higher pH. And, any amendment (e.g., FGD) which can neutralize soil acidity and raise soil $\mathrm{pH}$ close to neutral level would be appropriate for improving mine soil quality. In addition, chemical analysis of soils and soil solutions indicated absence of any significant phytotoxic element in these soils. Concentrations of most elements in these two mine soils were similar to those in regular agricultural soils in the region (Kabata-Pendias \& Pendias, 1984), and thus are not major factors limiting vegetation establishment on these coal-mining sites. For soils with $\mathrm{pH}$ values close to neutral, other factors such as nutrient availability and water holding capacity may be more important to vegetation establishment, and those amendments which can only increase soil $\mathrm{pH}$ would not significantly benefit vegetation establishment and growth.

\subsection{Effects of Amendments on Soil Physical Properties}

Mine soils, especially, the coarse coal refuse, often have poor soil physical properties such as high sand fraction, high bulk density, low aggregate stability, and low available water capacity and high soil strength. These poor physical properties are cause of susceptibility of vegetation to drought and mechanical impedance to root penetration, and high risks of soil erosion leading to adverse effects on plant establishment and growth (McFee et al., 1981; Daniels \& Stewart, 2000). Thus, effects of the amendments were assessed on physical properties (i.e., aggregate stability and water-holding capacity) of these two mine soils.

\subsubsection{Water Stable Aggregates}
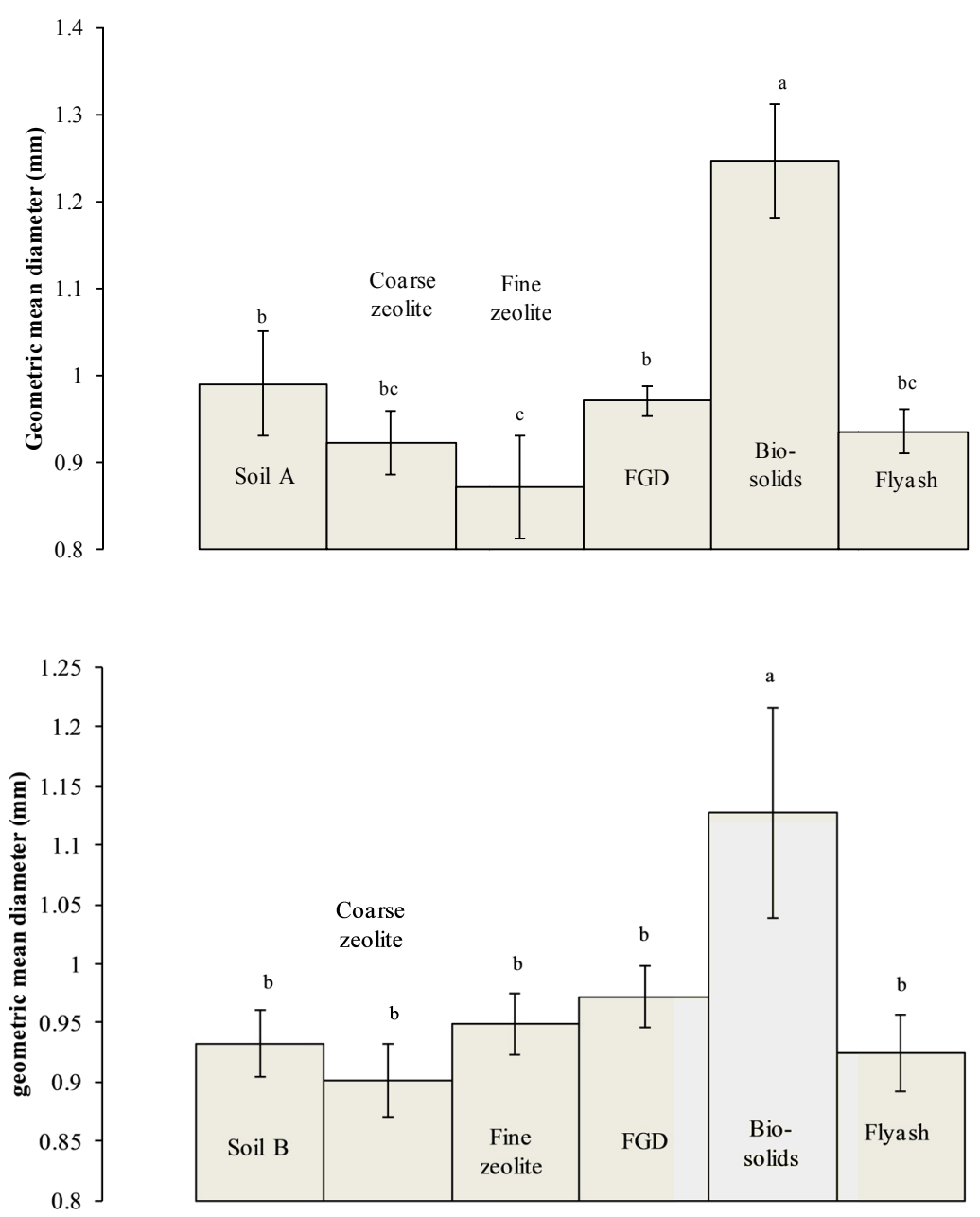

Figure 4. Effects of amendments on mean weigh diameter of water-stable aggregates in soil A (top) and soil B (bottom). Error bars represent standard deviation. Values with lowercase letters are significantly different by Tukey test $(\mathrm{p}<0.05)$ 
Water stability of aggregates (WSA) is an important physical characteristic of agricultural soils. It is a measure of the susceptibility of aggregates to dispersion by the kinetic energy of water. More specifically, it measures the extent to which soil aggregates are likely to remain intact and separate from one another through rain and mechanical disturbance (Kemper \& Rosenau, 1986). The data in Figure 4 show that use of biosolids significantly increased the geometric mean diameters (GMDs) of both soils. The GMD of aggregates in soil A was 1.3 times larger, and increased from 0.99 to $1.25 \mathrm{~mm}$. Similarly, GMD of soil B aggregates was 1.2 times larger, and increased from 0.93 to $1.13 \mathrm{~mm}$. These trends indicate the beneficial role of biosolids in enhancing aggregate stability. Other amendments such as FGD or flyash did not significantly improve the stability of soil aggregates. On the contrary, application of zeolites had a negative effect and reduced the GMD of soil A (Figure 4).

Although this is the first related report on mine soils, enhancing agricultural soil aggregation through biosolids amendments has been reported by several researchers (Garcia-Orenes et al., 2005; Ojeda et al., 2008; Wallace et al., 2009). For example, after 2 years of digested biosolids application to a soil surface at a rate of $15 \mathrm{Mg} \mathrm{ha}^{-1}$, Ojeda et al. (2008) reported that the GMD of a loamy soil increased from 2 to $2.5 \mathrm{~mm}$. The aggregate stability percentage of two soils studied by Garcia-Orences et al. (2005) increased by 1.8-3.7 folds in comparison to that of the control. Wallace et al. (2009) reported that application of $60 \mathrm{Mg} \mathrm{ha}^{-1}$ of dry biosolids resulted in about $50 \%$ more large aggregates $(2-6 \mathrm{~mm})$ relative to that of the control and the GMD increased from 1.2 to $1.5 \mathrm{~mm}$. Application of biosolids provides the soil with abundant SOM as an aggregate-binding agent and increases the soil aggregate size and stability. In contrast, the inorganic amendments (i.e., zeolite, FGD, and fly-ash) did not improve soil aggregation because of lack of any cementing organic matter. Salé et al. (1996) reported decreases in soil aggregate stability and GMD by use of a flyash.

\subsubsection{Water Holding Capacity}

High soil WHC is very important to a successful re-vegetation on a closed mining site where the plant-available water depends only on precipitation. However, predominately coarse-textured mine soils often have low WHC. The data in Figure 5 show that the saturated water holding capacity (SWHC) was $61.9 \%$ for soil A and $52.3 \%$ for soil B. Application of fine zeolite significantly increased the SWHC of soil A by $4 \%$ to $65.9 \%$, because of the fine grain size of the zeolite $(<0.04 \mathrm{~mm})$ and an increase in the clay + silt fraction in soil A by the amendment. However, application of flyash significantly reduced the SWHC of soil A by $3 \%$, down to $58.7 \%$, probably because of the hydrophobicity of the ash created at a high temperature. It has been reported that use of flyash could reduce field moisture capacity at low rates of $<10 \%$ but increase it at high rates of $>25 \%$ (Chang et al., 1977). Garg et al. (2005) also reported that at low rates $\left(4\right.$ and $\left.8 \mathrm{Mg} \mathrm{ha}^{-1}\right)$, application of flyash had no effects on SWHC but increased it by $3 \%$ at $12 \mathrm{Mg} \mathrm{ha}^{-1}$. Adriano \& Weber (2001) observed that increase in WHC became significant with flyash application rates higher than $560 \mathrm{Mg} \mathrm{ha}^{-1}$, but the plant available water increased significantly only at the highest rate of $1120 \mathrm{Mg} \mathrm{ha}^{-1}$. However, Pathan et al. (2003) reported that flyash application significantly increased the SWHC (doubled) of two soils at the rate of $10 \%$ by weight, suggesting that effects of fly-ash on the soil WHC depend both on the fly-ash type (source) and the application rate.

Neither biosolids nor FGD significantly affected the SWHC of soil A, and no single amendment significantly altered that of soil B, again indicating its strong dependence on soil type, amendment type, and amendment rate. The effects on SWHC by these amendments at $10 \%$ application rate were generally $<5 \%$ as observed in this report. Therefore, additional laboratory tests on different soils would be necessary to determine the specific effects on WHC at different application rates prior to their application in the field. 

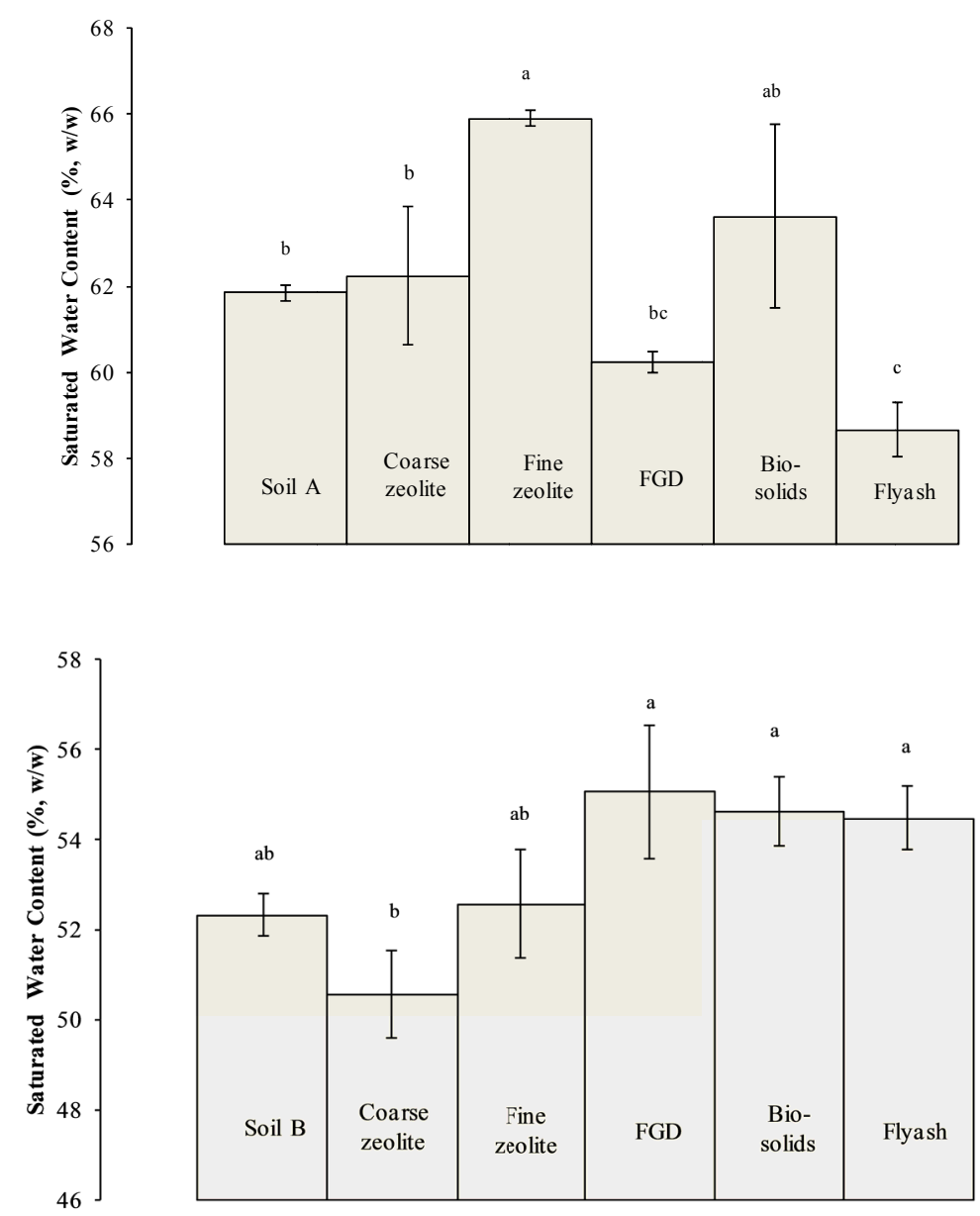

Figure 5. Effects of amendments on saturated water content of soil A (top) and soil B (bottom). Error bars represent standard deviation. Values with lowercase letters are significantly different by Tukey test $(p<0.05)$

The initial plant-available water capacity (PAWC) of soil A and soil B were 17.5 and $16.9 \%$ (Figure 6), respectively. Increase in PAWC (on volume basis) is needed to minimize the risks of drought. However, at the application rate of $10 \%$ by weight, none of the amendments significantly altered PAWC of soil A. In soil B, coarse zeolite decreased the PAWC by $2.6 \%$ (to $14.3 \%$ ), and FGD increased it by $2.7 \%$ (to $19.6 \%$ ). Being influenced by numerous interacting factors, PWAC of soil A or B was not strongly affected $(<3 \%)$ by these amendments tested in this study. Higher application rates might enhance the PAWC, which requires additional research under laboratory and field conditions. 

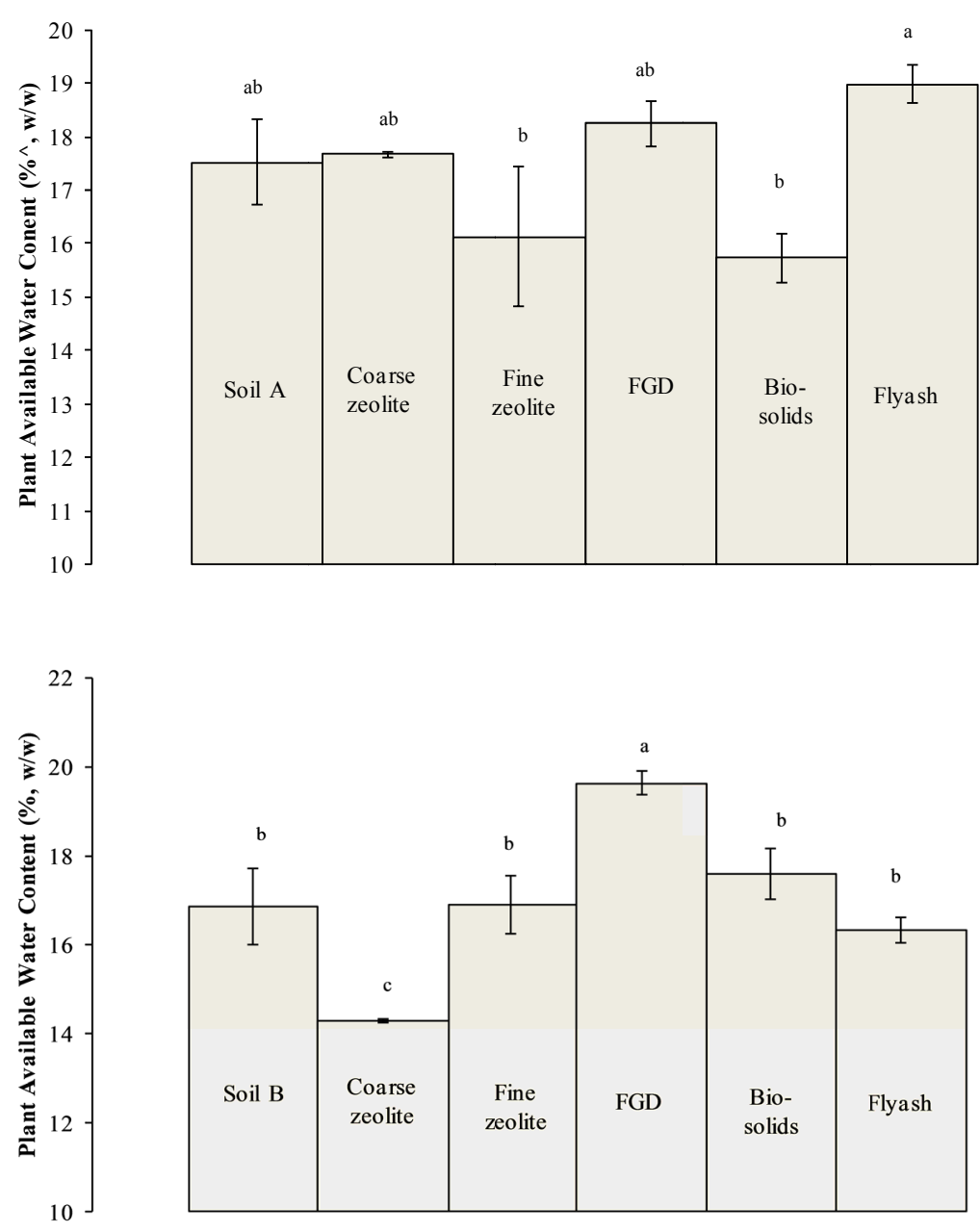

Figure 6. Effects of amendments on plant-available water holding capacity of soil A (top) and soil B (bottom). Error bars represent standard deviation. Values with lowercase letters are significantly different by Tukey test ( $p$ $<0.05)$

\section{Conclusions}

The data presented for two types of mine soils (coarse coal refuse) support the following conclusions:

i. Elemental analyses did not show high levels of contaminants in the mine soils or in the soil solutions, indicating that the low soil $\mathrm{pH}$ of 3-4 was the only chemical factor inhibiting vegetation.

ii. Application of FGD increased soil pH from 3.80 to 6.60 for soil A and 4.66 to above 5.70 for soil B, respectively.

iii. Growth of germinated lettuce seeds in soil solutions was significantly enhanced by FGD, from an initial shoot length of $2.9-4.7 \mathrm{~cm}$ to $5.9-8.6 \mathrm{~cm}$.

iv. Application of biosolids increased the mean weight diameters of water-stable aggregates from an initial 0.93- $0.99 \mathrm{~mm}$ to $1.13-1.25 \mathrm{~mm}$ for both soils.

v. A high level of $\mathrm{Zn}\left(2330 \mathrm{mg} \mathrm{kg}^{-1}\right)$ in the biosolids may cause secondary contamination under field conditions.

vi. Neither the use of flyash nor of two sizes of zeolites, significantly improved the mine soil quality.

This study suggests that low soil $\mathrm{pH}$ is the major factor inhibiting re-vegetation of reclaimed coal-mining sites. Application of FGD or lime can increase the soil $\mathrm{pH}$ and improve vegetation establishments. 


\section{Acknowledgments}

We wish to acknowledge the following individuals: Mr. Basant for laboratory assistance; Mrs. Lisa Butch (The former Little Beaver Creek Land Foundation, Ohio, 2011) for coal-mining soil samples; St Cloud Inc. (New Mexico) for zeolites; America Electric Power Inc. (Ohio) for fly-ash and FGD, and Columbus Wastewater Treatment Plant for biosolids. This work was financially supported by the former Ohio Department of Development, currently known as Ohio Development of Service Agency, Ohio, USA.

\section{References}

Adriano, D. C., \& Weber, J. T. (2001). Influence of fly-ash on soil physical properties and turgrass establishment. Journal of Environmental Quality, 30, 596-601. http://dx.doi.org/10.2134/jeq2001.302596x

Angel, P. N., Barton, C. D., Warner, R. C., Agouridis, C., Taylor, T., \& Hall, S. L. (2008). Forest establishment and water quality characteristics as influenced by spoil type on a loose-graded surface mine in eastern Kentucky. In R. I. Barnhisel (Ed.) Proceedings of the National Meeting of the American Society of Mining and Reclamation: New Opportunities to Apply Our Science (Richmond, VA. 14-19 June 2008, pp. 28-65). Lexington, KY: American Society for Surface Mining \& Reclamation.

Bendfeldt, E. S., Burger, J. A., \& Daniels, W. L. (2001). Quality of amended mine soils after sixteen years. Soil Science Society of America Journal, 65, 1736 -1744. http://dx.doi.org/10.2136/sssaj2001.1736

Bhumbla, D. K., Singh, R. N., \& Keefer, R. F. (2000). Coal combustion by-product utilization for land reclamation. In R. I. Barnhisel, R. G. Darmody \& W. L. Daniels (Eds.), Reclamation of Drastically Disturbed Lands (pp. 489-512). Madison, WI: American Society of Agronomy, Crop Science Society of America; \& Soil Science Society of America.

Bohn, H. L., McNeal, B. L., \& O’Connor, G. A. (1979). Soil Chemistry. New York, NY: John Wiley \& Sons.

Bowers, N., Pratt, J. R., Beeson, D., \& Lewis, M. (1997). Comparative evaluation of soil toxicity using lettuce seeds and soil ciliates. Environmental Toxicology \& Chemistry, 16, 207-213. http://dx.doi.org/10.1002/etc.5620160216

Bremner, J. M. (1996). Nitrogen-total. In D. L. Sparks (Ed.), Methods of Soil Analysis, Part III, Chemical Methods (pp. 1085-1121). Madison, WI: American Society of Agronomy, Crop Science Society of America, \& Soil Science Society of America.

Carter, C. M., Van Der Sloot, H. A., \& Colling, D. (2009). pH-dependent extraction of soil and soil amendments to understand the factors controlling element mobility. European Journal of Soil Science, 60, 622-637. http://dx.doi.org/10.1111/j.1365-2389.2009.01139.x

Cassel, D. K., \& Nielsen, D .R. (1986). Field capacity and available water capacity. In A. Klute (Ed.), Methods of Soil Analysis, Part I, Physical and Mineralogical Methods (2nd edition) (pp. 635-662). Madison, WI: American Society of Agronomy \& Soil Science Society of America.

Chang, A. C., Lund, L. J., Page, A. L., \& Warneke, J. E. (1997). Physical properties of fly-ash-amended soils. Journal of Environmental Quality, 6, 267-270. http://dx.doi.org/10.2134/jeq1977.00472425000600030007x

Chen, L., Dick, W. A., \& Nelson, S. (2001). Flue gas desulfurization by-products additions to acid soil: alfalfa productivity and environmental quality. Environmental Pollution, 114, 161-168. http://dx.doi.org/10.1016/S0269-7491(00)00220-7

Clark, R. B., Ritchey, K. D., \& Baligar, V. C. (2001). Benefits and constraints for use of FGD products on agricultural land. Fuel, 80, 821-827. http://dx.doi.org/10.1016/S0016-2361(00)00162-9

Coyne, M. S., Zhai, Q., Mackown, C. T., \& Barnhisel, R. I. (1998). Gross nitrogen transformation rates in soil at a surface coal mine site reclaimed for prime farmland use. Soil Biology \&. Biochemistry, 30, 1099-1106. http://dx.doi.org/10.1016/S0038-0717(97)00202-2

Crews, J. T., \& Dick, W. A. (1998). Liming acid forest soils with flue gas desulfurization by-product: Growth of Northern read oak and leachate water quality. Environmental Pollution, 103, 55-61. http://dx.doi.org/10.1016/S0269-7491(98)00137-7

Crowell, D. L. (1995). History of the Coal-Mining Industry in Ohio. Columbus, OH: Division of Geological Survey \& Ohio Department of Natural Resources.

Daniels, W. L., \& Haering, K. C. (1994). Use of sewage sludge for land reclamation in the central Appalachians. In C. E. Clapp, W. E. Larson \& R. H. Dowdy (Eds.), Sewage Sludge: Land Utilization and the Environment (pp. 
105-121). Madison, WI: American Society of Agronomy, Crop Science Society of America, \& Soil Science Society of America.

Daniels, W. L., \& Stewart, B. R. (2000). Reclamation of Appalachian coal refuse disposal areas. In R. I. Barnhisel, R.G. Darmody \& W.L. Daniels (Eds.), Reclamation of Drastically Disturbed Lands (pp. 433-459). Madison, WI: American Society of Agronomy, Crop Science Society of America, \& Soil Science Society of America.

Daniels, W. L, Stewart, B. R., Haering, K. C., \& Zipper, C. (2002). The Potential for Beneficial Reuse of Coal Flyash in Southwest Virginia Mining Environments. Virginia Cooperative Extension (VCE) publication 460-134. Retrieved from http://ww.pubs.ext.vt.edu/460-134

Daniels, W. L., Stewart, B. R., \& Zipper, C. E. (2010). Reclamation of Coal Refuse Areas. Virginia Cooperative Extension (VCE) publication 460-131. Retrieved from http://pubs.ext.vt.edu/460/460-131/460-131_pdf

Daniels, W. L., \& Zipper, C. E. (2010). Creation and Management of Productive Mining Soil. Virginia Cooperative Extension (VCE) publication 460-121. Retrieved from http://pubs.ext.vt.edu/460/ 460-121/460-121_pdf

Dick, W. A., Hao, Y. L., Stehouwer, R. C., Bigham, J. M., Wolfe, W. E., Adriano, D., ... Haefner, R. J. (2000). Beneficial uses of flue gas desulfurization by-products: Examples and case studies of land application. In J. F. Power \& W. A. Dick (Eds.), Land Application of Agricultural, Industrial, and Municipal By-Product (pp. 505-536). Madison, WI: Soil Science Society of America.

Dudka, S., \& Adriano, D. C. (1997). Environmental impacts of metal ore mining and processing: A review. Journal of Environmental Quality, 26, 590-602. http://dx.doi.org/10.2134/jeq1997.263590x

Forsberg, L. S., \& Ledin, S. (2006). Effects of sewage sludge on $\mathrm{pH}$ and plant availability of metals in oxidising sulphide mine tailings. Science of the Total Environment, 358, 21-35. http://dx.doi.org/10.1016/j.scitotenv.2005.05.038

García-Orenes, F., Guerrero, C., Mataix-Solera, J., Navarro-Pedrenõ, J., Gómez, I., \& Mataix-Beneyto, J. (2005). Factors controlling the aggregate stability and bulk density in two different degraded soils amended with biosolids. Soil \& Tillage Research, 82, 65-76. http://dx.doi.org/10.1016/j.still.2004.06.004

Garg, R. N., Pathak, H., Das, D. K., \& Tomar, R. K. (2005). Use of flyash and biogas slurry for improving wheat yield and physical properties of soil. Environmental Monitoring \& Assessment, 107, 1-9. http://dx.doi.org/10.1007/s10661-005-2021-x

Gelfand, I., Sahajpal, R., Zhang, X., Izaurralde, R. C., Gross, K. L., \& Robertson, G. P. (2013). Sustainable bioenergy production from marginal lands in the US Midwest. Nature (in press). http://dx.doi.org/10.1038/nature11811

Haering, K. C., Daniels, W. L., \& Feagley, S. E. (2000). Reclaiming mined lands with biosolids, manures and papermill sludges. In R. I. Barnhisel, R .G. Darmody \& W. L. Daniels (Eds.), Reclamation of Drastically Disturbed Lands (pp. 615-644). Madison, WI: American Society of Agronomy, Crop Science Society of America, \& Soil Science Society of America.

Illera,V., Garrido, F., Vizacyno, C., \& García-González, M. T. (2004). Field application of industrial by-products asAl toxicity amendments: chemical and mineralogical implications. European Journal of Soil Science, 55, 681-692. http://dx.doi.org/10.1111/j.1365-2389.2004.00640.x

Jacinthe, P. A., \& Lal, R. (2007). Carbon storage and minesoil properties in relation to topsoil application techniques. Soil Science Society of America Journal, 71, 1788-1795. http://dx.doi.org/10.2136/sssaj2006.0335

Kabata-Pendias, A., \& Pendias, H. (1984). Trace Elements in Soils and Plants. Boca Raton, FL: CRC Press.

Kepmer, W. D., \& Rosenau, R. C. (1986). Aggregate stability and size distribution. In A. Klute (Ed.), Methods of Soil Analysis, Part I, Physical and Mineralogical Methods (2nd edition) (pp. 425-442). Madison, WI: American Society of Agronomy \& Soil Science Society of America.

Kost, D. A., Bigham, J. M., Stehouwer, R. C., Beeghly, J. H., Fowler, R., Traina, S. J., ... Dick, W. A. (2005). Chemical and physical properties of dry flue gas desulfurization products. Journal of Environmental Quality, 34, 676-686. http://dx.doi.org/10.2134/jeq2005.0676

Lal, R., \& Bruce, J. P. (1999). The potential of world cropland to sequester carbon and mitigate the greenhouse effect. Environmental Science \& Policy, 2, 177-185. http://dx.doi.org/10.1016/S1462-9011(99)00012-X 
Larney, F. J., Akinremi, O. O., Lemke, R. L., Klaassen, V. E., \& Janzen, H. H. (2005). Soil responses to topsoil replacement depth and organic amendments in wellsite reclamation. Canadian Journal of Soil Science, 85, 307-317. http://dx.doi.org/10.4141/S04-035

Li, R. S., \& Daniels, W. L. (1997). Reclamation of coal refuse with a papermill sludge amendment. National Meeting of the American Society for Surface Mining and Reclamation (pp. 277-289). Austin, TX, May 10-15.

McFee, W. W., Byrnes, W. R., \& Stockton, J. G. (1981). Characteristics of coal mine overburden important to plant growth. Journal of Environmental Quality, 10, 300-308. http://dx.doi.org/10.2134/jeq1981.00472425001000030009x

Nabuurs, G. J., Dolman, A. J., Verkaik, E., Kuikman, P. J., Van Diepen, C. A., Whitmore, A. P. ... Mohren, G. M. J. (2000). Article 3.3 and 3.4 of the Kyoto protocol: Consequences for industrialized countries' commitment, the monitoring needs and possible side effects. Environmental Science \& Policy, 3, 123-134. http://dx.doi.org/10.1016/S1462-9011(00)00006-X

Nandi, A., \& Luffman, I. (2012). Erosion related changes to physicochemical properties of Ultisols distributed on calcareous sedimentary rocks. Journal of Sustainable Development, 5, 52-68. http://dx.doi.org/10.5539/jsd.v5n8p52

National Mining Association. (2012). 2011 Coal Producer Survey. Retrieved from http://www.nma.org/pdf/members/coal_producer_survey2011.pdf

Nelson, D. W., \& Sommers, L. E. (1996). Total carbon, organic carbon, and organic matter. In D. L. Sparks (Ed.), Methods of Soil Analysis, Part III, Chemical Methods (pp. 961-1010). Madison, WI: American Society of Agronomy, Crop Science Society of America, \& Soil Science Society of America.

Ojeda, G., Alcaniz, J. M., \& Bissonnais, Y. L. (2008). Differences in aggregate stability due to various sewage sludge treatments on a Mediterranean calcareous soil. Agriculture, Ecosystems \& Environment, 125, 48-56. http://dx.doi.org/10.1016/j.agee.2007.11.005

Pathan, S. M., Aylmore, A. G., \& Colmer, T. D. (2003). Properties of several flyash materials in relation to use as soil amendments. Journal of Environmental Quality, 32, 687-693. http://dx.doi.org/10.2134/jeq2003.0687

Pérez-estebana, J., Escolásticoa, C., Masaguerb, A., \& Molinerb, A. (2012). Effects of sheep and horse manure and pine bark amendments on metal distribution and chemical properties of contaminated mine soils. European Journal of Soil Science, 63, 733-742. http://dx.doi.org/10.1111/j.1365-2389.2012.01468.x

Roberts, J. A., Daniels, W. L., Bell, J. C., \& Zipper, C. E. (1988). Early stages of mine soil genesis as affected by topsoiling and organic amendments. Soil Science Society of America Journal, 52, 730-738. http://dx.doi.org/10.2136/sssaj1988.03615995005200030025x

Salé, L. Y., Chanasyk, D. S., \& Naeth, M. A. (1996). Temporal influence of fly ash on soil bulk density and aggregate size distribution. Proceedings of the 20th Annual British Columbia Mine Reclamation Symposium, (pp. 184-195). Kamloops, British Columbia, Canada.

Sambou, A., Ndour, B., Cheng, S., \& Senghor, E. (2010). Ligneous species tolerance in acid sulphated and saline soils of Sine Saloum: Case of rural community of Dajilaas and Loul Secene. Journal of Sustainable Development, 3, 174-186.

Shipitalo, M. J., \& Bonta, J. V. (2008). Impact of using paper mill sludge for surface-mine reclamation on runoff water quality and plant growth. Journal of Environmental Quality, 37, 2351-2359. http://dx.doi.org/10.2134/jeq2007.0648

Shrestha, R. K., Lal, R., \& Jacinthe, P. A. (2009). Enhancing carbon and nitrogen sequestration in reclaimed soils through organic amendments and chiseling. Soil Science Society of America Journal, 73, 1004-1011. http://dx.doi.org/10.2136/sssaj2008.0216

Shukla M., Lal, R., \& Ebinger, M. H. (2005). Physical and chemical properties of a minespoil eight years after reclamation in northeastern Ohio. Soil Science Society of America Journal, 69, 1288-97. http://dx.doi.org/10.2136/sssaj2004.0221

Soltanpour, P. N., Johnson, G. W., Workman, S. M., Jones, J. B. Jr., \& Miller R. O. (1996). Inductively coupled plasma emission spectrometer and inductively coupled plasma-mass spectrometry. In D. L Sparks (Ed.), Methods of Soil Analysis, Part III, Chemical Methods (pp. 91-139). , Madison, WI: American Society of Agronomy, Crop Science Society of America, \& Soil Science Society of America. 
Stewart, B. R., \& Daniels, W. L. (1992). Physical and chemical properties of coal refuse from Southwest Virginia. $\begin{array}{lllll}\text { Journal of Environmental } & \text { Quality, } & \text { 635-642. }\end{array}$ http://dx.doi.org/10.2134/jeq1992.00472425002100040018x

Stewart, B. R., Daniels, W. L., Zelazny, L. W., \& Jackson, M. L. (2001). Evaluation of leachates from cola refuse blended with fly ash at different rates. Journal of Environmental Quality, 30, 1382-1391. http://dx.doi.org/10.2134/jeq2001.3041382x

Tan, K. H. (2005). Soil Sampling, Preparation, and Analysis (2nd ed.). Boca Raton, FL: Taylor \& Francis.

Thomas, G. W. (1996). Soil pH and soil acidity. In D.L. Sparks (Ed.), Methods of Soil Analysis, Part III, Chemical Analysis (pp. 475-489). Madison, WI: American Society of Agronomy, Crop Science Society of America, \& Soil Science Society of America.

Thompson, T. L., Hopkins, M. W., \& White, S. A. (2001). Reclamation of copper mine tailings using biosolids and green waste. In R. Vincent (ed.), Proceedings of 2001: Land reclamation: a different approach. 18th annual meeting of the American society for surface mining and reclamation (Albuquerque, NM, June 3-7, 2001) (pp. 448-56). Lexington, KY: American Society for Surface Mining \& Reclamation.

Tilman, D., Hill, J., \& Lehman, C. (2006). Carbon-negative biofuels from low-input high diversity grassland biomass. Science, 314, 1598-1600. http://dx.doi.org/ 10.1126/science.1133306

USEPA-United States Environmental protection Agency. (2009). National Secondary Drinking Water Regulations. Retrieved from http://water.epa.gov/ drink/ contaminants /index.cfm\#Inorganic.

USEPA-United States Environmental Protection Agency: Office of Water. (2000). Biosolids Technology fact sheet: Alkaline stabilization of biosolids. EPA 832-F-00-052. Retrieved from http://www.epa.gov/region8/water/biosolids/.../BiosolidsTechSheetAlk.pdf

Wallace, B. M., Krzic, M., Forge, T. A., Broersma, K., \& Newman, R. F. (2009). Biosolids increase soil aggregation and protection of soil carbon five years after application on a crested wheatgrass pasture. Journal of Environmental Quality, 38, 291-298. http://dx.doi.org/ 10.2134/jeq2007.0608

Wang, J., Solomon, D., Lehmann, J., Zhang, X., \& Amelung, W. (2006). Soil organic sulfur forms and dynamics in the Great Plains of North America as influenced by long-term cultivation and climate. Geoderma, 133, 160-172. http://dx.doi.org/10.1016/j.geoderma.2005.07.003

\section{Copyrights}

Copyright for this article is retained by the author(s), with first publication rights granted to the journal.

This is an open-access article distributed under the terms and conditions of the Creative Commons Attribution license (http://creativecommons.org/licenses/by/3.0/). 